\title{
Community structure of the euphausiid populations along the west coast of Baja California, Mexico, during the weak ENSO 1986-1987
}

\author{
J. Gómez-Gutiérrez, R. Palomares-García, D. Gendron \\ Centro Interdisciplinario de Ciencias Marinas, Departamento de Plancton y Ecología Marina, Apdo Postal 592, \\ CP 23000 La Paz, Baja California Sur, México
}

\begin{abstract}
Changes in the community structure and distribution patterns of 20 species of euphausiids collected during 6 oceanographic cruises along the southwest coast of Baja California during El Niño Southern Oscillation (ENSO) 1986-1987 were compared with the data from 5 cruises made during ENSO 1982-1983. The possible existence of different influences of environmental conditions on the distribution, abundance, and community structure of euphausiids during the 2 periods was assessed. Although a time series of surface temperature (SST) from 3 latitudinal regions along the west coast of Baja California during 1980 and 1990 showed no evidence of a long-term warming in 1986 and early 1987 , a positive SST anomaly $\left(1^{\circ} \mathrm{C}\right)$ was observed during the second half of 1987 , reaching latitude $26^{\circ} \mathrm{N}$. The composition of species during this study showed a high proportion of tropical and equatorial endemic Eastern Tropical Pacific (ETP) species, north and south margin ETP proliferator species, and warm water cosmopolitan species. There was a scarcity of California Current terminus species. Euphausia pacifica Hansen and Thysanoessa gregaria G. O. Sars, 2 temperate species, were considered to have moved from their reproductive areas. Nyctiphanes simplex Hansen dominates the euphausiid fauna of the west coast of Baja California and was most plentiful near the shore. Its reproductive activity was mainly in upwelling regions. Seasonal and latitudinal variability of the intensity of the upwelling along the peninsula could have a strong influence on the range of distribution of its highest abundance centers. The southern region was dominated by tropical and equatorial endemic ETPadapted species showing reproductive activity. Compared to ENSO 1982-1983, the influence of ENSO 1986-1987 on the community of euphausiids in the southern part of Baja California was small.
\end{abstract}

KEY WORDS: Euphausiid ENSO Community structure B Baja California - Mexico

\section{INTRODUCTION}

The effect of environmental conditions on marine organisms is complex. It is related to factors that interact with different time-space scales. These interactions are most difficult to understand because of the varying influence of environmental conditions on different species during all or part of their life history. Usually, zooplanktonic organisms have a wide distribution. However, knowledge of the life history and the breeding season of each species is of great importance to ascertain the area in which the species finds optimal or tolerable conditions for reproduction (Johnson \& Brinton 1963).
The highly variable environmental conditions along the west coast of the Baja California Peninsula, Mexico, which is recognized as a transition zone between North, Central, and Eastern Tropical Pacific water masses (Roden 1971 , Brinton \& Reid 1986), have an important influence on the seasonal variability of the specific composition and distribution of the euphausiids (Gómez 1992). Studies of interannual variability of abiotic conditions along the coast of America have confirmed the existence of climatic anomalies resulting from strengthening of the equatorial circulation system as a response to El Niño Southern Oscillation (ENSO) events (McGowan 1984, Cole \& McLain 1989). 
The effects of previous ENSO occurrences, particularly ENSO 1982-1983, the most intense surface warming of the century, on the zooplanktonic organisms of the regions of California (USA), Baja California, and Gulf of California (Mexico) have been described (Brinton 1981, Brinton \& Reid 1986, Brodeur 1986. Green 1986, Lavaniegos et al. 1989, Lavaniegos \& Lara 1990). During ENSO events, it appeared that euphausiids constituted a higher than usual proportion of the total catch (Smith 1985, Brinton \& Reid 1986). Euphausiid species having affinities with warm offshore and southerly waters of the California Current could shift from offshore and southern regions, and therefore several species like Nyctiphanes simplex Hansen were displaced northward (Brinton 1981). Seasonal influence of different water masses and longscale processes, like ENSO events, which could change the distribution patterns of the euphausiids make it difficult to describe 'normal conditions' of the community structure in this area, unlike the welldelimited distribution patterns found in the community structure of euphausiids in the Benguela Current system where along-shore temperature gradients are not very marked (Barange et al. 1992). The 1986-1987 ENSO event was detected in the Eastern Tropical Pacific (ETP) by Almeyda (1987), Cole \& McLain (1989), Lander (1989) and McPhander et al. (1990). The effect on the zooplanktonic organisms in the California Current system during this event has not been studied. Our purpose was to explore the effects of the environmental conditions of 1986 and 1987 on the distribution and abundance of the euphausiid populations along the west coast of Baja California.

\section{MATERIALS AND METHODS}

Field sampling. Euphausiids were collected during 6 oceanographic cruises made along the west coast of Baja California during May, June, August, and November 1986, and July and October 1987 (Fig. 1). In addition, we obtained data on euphausiid abundance in the region $23^{\circ}$ to $25^{\circ} \mathrm{N}$ near Bahia Magdalena during July and November 1982, and March, May, and September 1983 (Green 1986) for comparison with our data base. Our samples and Green's samples were obtained with Bongo nets fitted with a calibrated flowmeter, and with $300 \mu \mathrm{m}$ and $500 \mu \mathrm{m}$ mesh nets, trawled from $210 \mathrm{~m}$ to the surface following the method of Smith \& Richardson (1977). Zooplankton biomass was recorded as displaced volume and normalized to $\mathrm{ml}$ per $1000 \mathrm{~m}^{-3}$ according to Beers (1976). Assuming that seasonal variability of biological and environmental conditions are higher than interannual variability over a short time period, we chose the May 1986 and July

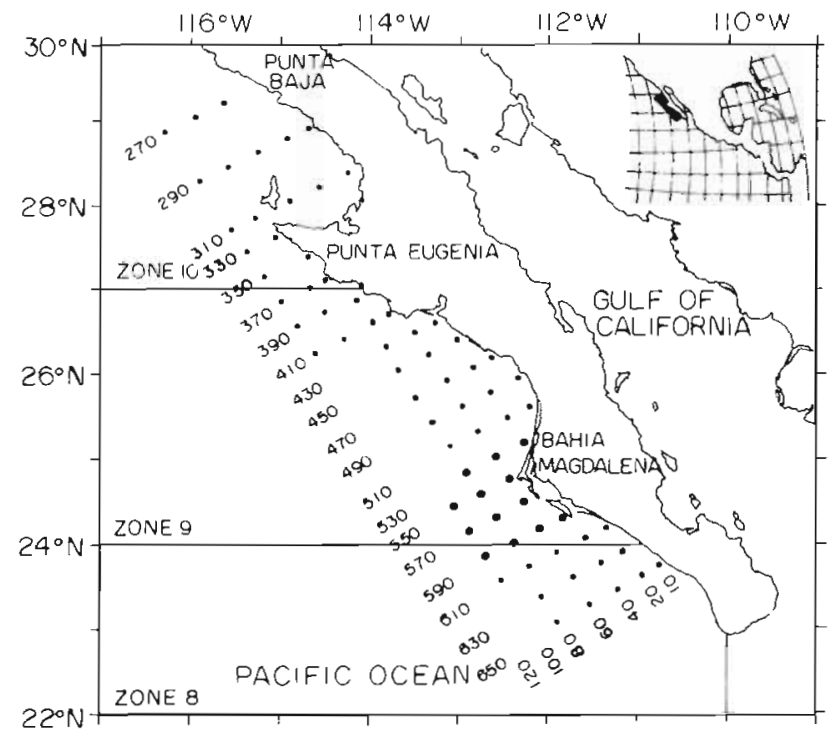

Fig. 1. CICIMAR stations divided into areas sampled along the west coast of Baja California, Mexico, during May 1986. July 1987, and October 1987. Large sampling points denote area (Bahia Magdalena) sampled during June, August, and

November 1986, and data obtained from Green (1986)

and October 1987 surveys with the maximum covered areas as examples of conditions found during spring. summer, and autumn, respectively.

Euphausiid analysis. The samples collected from the $505 \mu \mathrm{m}$ mesh net were subsampled with a Folsom splitter when the volume of zooplankton biomass was greater than $20 \mathrm{ml}$. Samples with less than $20 \mathrm{ml}$ zooplankton were analyzed in their entirety. All life stages of euphausiids were identified and counted. The sexual maturity of the euphausiids was determined by identifying the spermatophore of males and looking for the spermatophore adhering to the thelycum of the female or for the internal ripe ovary and ovigerous sacs of the females. The numbers of euphausiids were normalized to $1000 \mathrm{~m}^{-3}$ filtered water. Owing to the daily vertical migratory behavior of the juveniles and adults of most species studied along the west coast of Baja California (Brinton 1967, Youngbluth 1976), only nighttime stations have been considered in the analyses. For calyptopes and furciliae, both day- and night-time stations were included in the analyses because these stages are distributed in the first $100 \mathrm{~m}$ depth.

Data analysis. Euphausiid species found during May 1986 and July and October 1987 were grouped by biogeographic affinities in a horizontal space relation following the classification of Brinton (1979). To determine recurrent groups of the species (juveniles and adults), the similarity coefficient of Jaccard and the unweighted pair-group method using arithmetic averages (UPGMA) algorithm were used according to Ludwig \& Reynolds (1988), though modified to use data divided 
into above/below mean abundance rather than simple presence/absence data as done by Brinton (1979). Species like Euphausia hemigibba Hansen, E. diomedeae Ortmann, Nematoscells tenella G. O. Sars, Stylocheiron elongatum G. O. Sars, and Thysanopoda astylata Brinton found at less than $10 \%$ of the sampled stations were not included.

The time series of mean coastal surface temperatures (coastal SST values, ${ }^{\circ} \mathrm{C}$ ) reported by Cole \& McLain (1989) was used as a complement to CDROM NODC-01 Pacific Ocean (NOAA) during the period January 1980 to December 1990. Three coastal zones defined by Cole $\&$ McLain as zone $8\left(21^{\circ}\right.$ to $\left.24^{\circ} \mathrm{N}\right)$, zone $9\left(24^{\circ}\right.$ to $\left.27^{\circ} \mathrm{N}\right)$, and zone $10\left(27^{\circ}\right.$ to $\left.30^{\circ} \mathrm{N}\right)$ were compared. Preliminary analysis was made using anomalies. Noise was filtered by using 12-order running means according to Makridakis \& Weelwright (1978). The anomaly of the sea surface temperature (SST) of each zone was calculated as follows:

$$
Z_{i}=X_{1 J}-Y_{j}
$$

where $Z_{i j}$ is the anomaly of the $j$ th month in the $i$ th year, $X_{i j}$ is the variable value in the $j$ th month of the ith year, and $Y_{j}$ is the mean value in the $j$ th month.

\section{RESULTS}

\section{Environmental conditions}

A time series of SST from 3 latutudinal regions along the west coast of Baja Calıforma between January 1980 and December 1990 showed that the SST range in the northern zone $\left(27^{\circ}\right.$ to $\left.30^{\circ} \mathrm{N}\right)$ was clearly cooler (15.5 to $22.5^{\circ} \mathrm{C}$; Fig. $\left.2 \mathrm{~A}\right)$ than both the central $\left(24^{\circ}\right.$ to $\left.27^{\circ} \mathrm{N}\right)\left(16.5\right.$ to $27^{\circ} \mathrm{C}$; Fig. $\left.2 \mathrm{~B}\right)$ and the southern zone $\left(21^{\circ}\right.$ to $\left.24^{\circ} \mathrm{N}\right)\left(19\right.$ to $29^{\circ} \mathrm{C}$; Fig. $\left.2 \mathrm{C}\right)$, indicating a progressive north to south gradient of the SST. This time series showed the positive anomaly SST during 1982, 1983, and 1984. No evidence of a long-term warming durnng 1986 and 1987 was found, except during November and December 1987 at $24^{\circ}$ to $27^{\circ} \mathrm{N}$ and from July to December 1987 at $21^{\circ}$ to $24^{\circ} \mathrm{N}$, both showing a positive anomaly of about $1^{\circ} \mathrm{C}$. Between 1988 and 1989, a long-term cooling dominated along the 3 zones, particularly in the southern zone. In addition, during 1990, a positive anomaly along the west coast of Baja California was found.

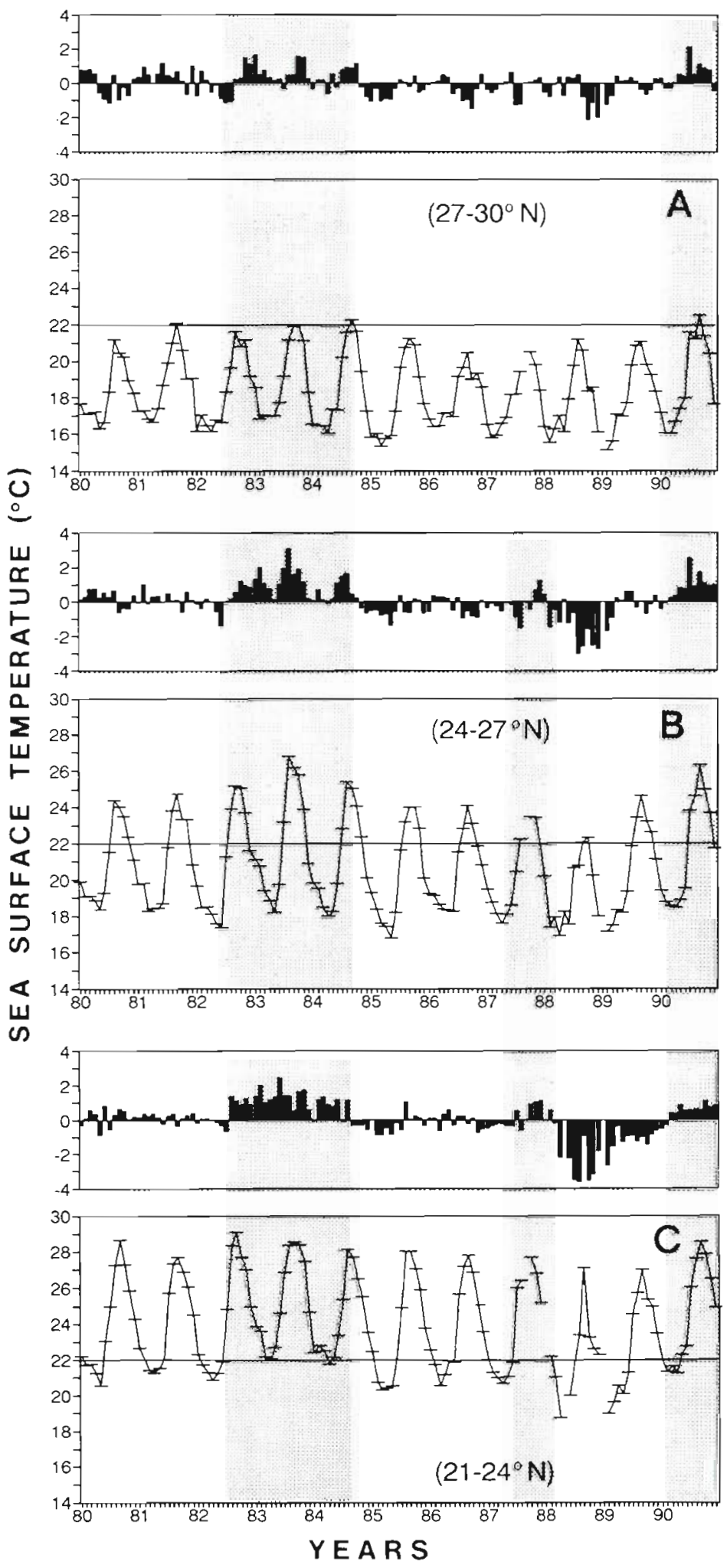

Fig 2 Time series of anomalies (barsi and mean coastal sea surface temperatures (coastal SST values) (hnes) reported by Cole \& McLam (1989) dunng the period January 1980 to December 1990 in 3 coastal zones defined by them as (A) zone 10, (B) zone 9 and (C) zone 8 Positive SST anomalies are indicated by shading 
Seasonal differences in the SST and zooplanktonic biomass were found between surveys. During maximum upwelling conditions, local peaks in zooplankton biomass were observed over the whole study area. During reduced upwelling, biomass peaks were restricted to the region of cooler waters. During abated upwelling conditions, zooplanktonic biomass was low (Fig. $3 \mathrm{~A}$ to $\mathrm{C}$ ). This shows a positive influence of the upwelling process on the zooplankton population, in agreement with previous work (Roesler \& Chelton 1987). Species which contribute to the highest zooplankton biomass in coastal upwelling areas are the euphausiid Nyctiphanes simplex, and the copepods Calanus pacificus Brodsky and Acartia danae Giesbrecht.

\section{Distribution and abundance of euphausiids}

During the study periods, 20 euphausiid species of 7 genera were found. Relative abundance $(\%)$, mean abundance (ind. per $1000 \mathrm{~m}^{-3}$ ), and standard deviation of larval stages (calyptopes and furciliae) and juveniles and adults of the euphausiid species for each survey are shown (Table 1).

The most abundant euphausiid during all surveys was Nyctiphanes simplex, with a relative abundance of 88 to $98 \%$ of total larvae and 65 to $94 \%$ of juveniles and adults collected. The second most abundant species was Euphausia eximia Hansen. Both species were considered the major component of the euphausiid biomass for all regions. Nematoscelis difficilis Hansen (juveniles and adults) was the second most abundant species in May 1986. The rest of the species generally showed a relatively low abundance of larvae, juveniles and adults, except the juveniles and adults of $\mathrm{Ne}$ matobrachion flexipes (Ortmann), Stylocheiron affine Hansen, and Euphausia distinguenda Hansen.

Recurrent group calculations with the Jaccard index showed 2 groups well separated in distribution during May 1986 (Fig. 4A). The first included species from the California Current terminus, like Nematoscelis difficilis, and the offshore part of the California Current, like Euphausia recurva Hansen, and including the margin ETP proliferator Nyctiphanes simplex, the most abundant species in the coastal water. The second group included tropical and equatorial species like E. distinguenda, and margin ETP proliferator species like E. eximia and Nematobrachion flexipes. Nematoscelis gracilis Hansen, a tropical species, appeared to be separate from the groups (Fig. 4A). During July 1987, the following 2 groups were well delimited: a tropical assemblage distributed in the southern waters including E. eximia, E. distinguenda, and Euphausia tenera Hansen, and a temperate assemblage in the

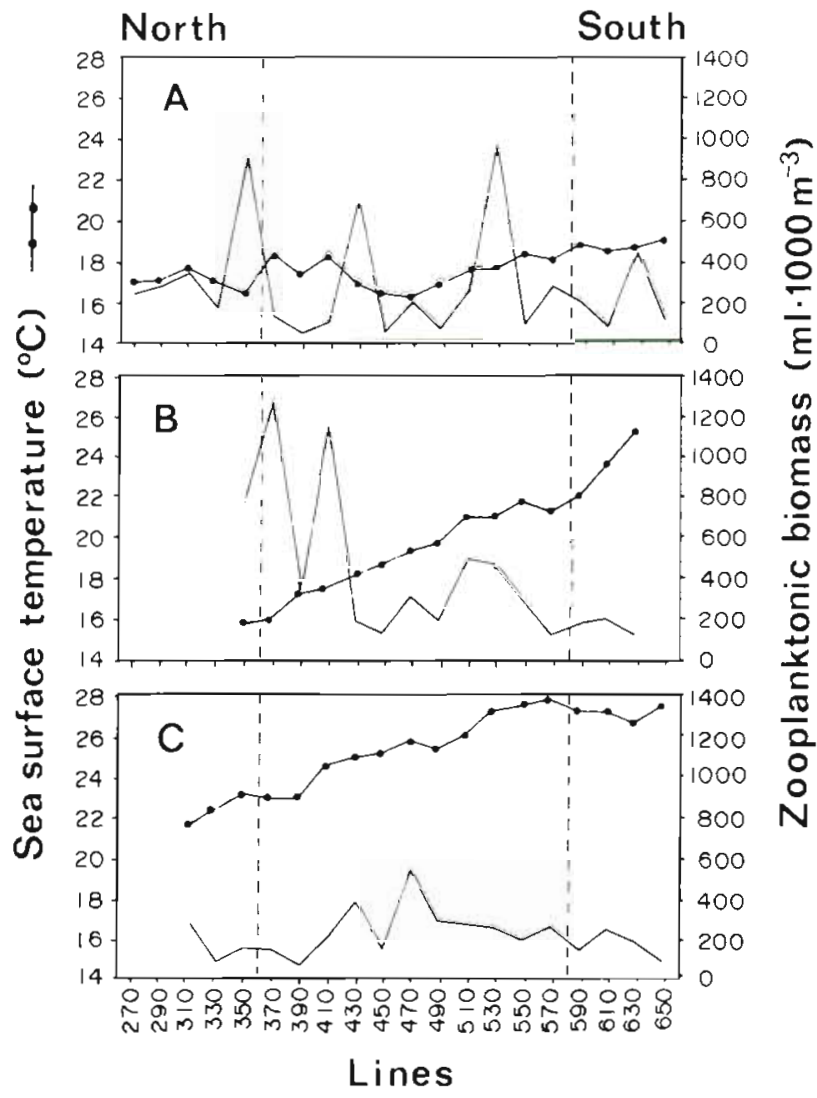

Fig. 3. Latitudinal variation of the SST and zooplanktonic biomass during (A) May 1986, (B) July 1987, and (C) October 1987. Dashed vertical line delimits Cole \& McLain's (1989) hydrographic areas, left side (zone 10), central (zone 9), and right side (zone 8 )

northern areas characterized by Euphausia gibboides Ortmann, $N$. difficilis, Stylocheiron affine, and Thysanoessa gregaria G. O. Sars. N. simplex and Euphausia lamelligera Hansen are 2 coastal species and were separated from the groups (Fig. 4B). During October 1987, we found 2 groups, one dominated by tropical species ( $E$. eximia and $E$. distinguenda) and the other a mixed assemblage of temperate and tropical species (i.e. E. gibboides, E. recurva, and E. tenera). Euphausia pacifica Hansen appeared separated from these groups (Fig. 4C).

The north-south line-by-line occurrences, together with indications of a species abundance greater than the mean and the presence of early larval stages (calyptopes), which would suggest the main reproductive areas, are given in Fig. 5. Euphausia pacifica was found only in May 1986 and October 1987 and is considered to have been displaced from its reproduction areas. There was no evidence of recent reproduction of this species, as indicated by finding only early larval stages or adults in the reproductive phase. The offshore part of the California Current species E. hemi- 
Table 1. Relative abundance (\%), mean abundance (ind. per $1000 \mathrm{~m}^{-3}$ ), and standard deviation of larval stages (calyptopes and furciliae) and juveniles and adults for each euphausiid species in all surveys

\begin{tabular}{|c|c|c|c|c|c|c|c|c|c|}
\hline \multirow{2}{*}{ Species } & \multicolumn{3}{|c|}{ May $1986(n=52)$} & \multicolumn{3}{|c|}{ July $1987(n=42)$} & \multicolumn{3}{|c|}{ October $1987(\mathrm{n}=26)$} \\
\hline & $\%$ & Mean & $\mathrm{SD}$ & $\%$ & Mean & SD & $\%$ & Mean & SD \\
\hline \multicolumn{10}{|l|}{ Calyptopes and furciliae } \\
\hline Nyctiphanes simplex & 96.690 & 9699.08 & 30423.03 & 88.533 & 14367.13 & 24256.34 & 98.277 & 17993.35 & 32662.24 \\
\hline Euphausia eximia & 1.549 & 155.43 & 483.63 & 11.238 & 1823.75 & 11071.03 & 1.504 & 275.41 & 1084.10 \\
\hline E. gibboides & 0.549 & 55.05 & 175.14 & 0.009 & 1.44 & 6.43 & 0.001 & 0.24 & 0.85 \\
\hline E. tenera & & & & 0.001 & 0.16 & 1.05 & & & \\
\hline \multicolumn{10}{|l|}{ E. hemigibba } \\
\hline \multicolumn{9}{|l|}{ E. diomedeae } & 39.93 \\
\hline E. recurva & 0.003 & 0.30 & 2.14 & & & & & & \\
\hline \multicolumn{10}{|l|}{ E. pacifica } \\
\hline \multicolumn{10}{|l|}{ E. lamelligera } \\
\hline Nematoscelis difficilis & 0.857 & 85.98 & 139.70 & 0.057 & 9.27 & 30.43 & 0.017 & 3.10 & 14.27 \\
\hline N. gracilis & 0.002 & 0.23 & 1.65 & 0.026 & 4.25 & 27.20 & & & \\
\hline \multicolumn{10}{|l|}{ N. tenella } \\
\hline Thysanoessa gregaria & 0.008 & 0.85 & 3.78 & 0.001 & 0.16 & 1.05 & & & \\
\hline Nematobrachion flexipes & 0.001 & 0.06 & 0.41 & 0.003 & 0.50 & 2.72 & 0.007 & 1.23 & 6.15 \\
\hline Stylocheiron affine & 0.237 & 23.82 & 34.89 & 0.080 & 12.91 & 40.93 & 0.097 & 17.81 & 28.32 \\
\hline S. maximum & 0.020 & 2.05 & 8.47 & 0.001 & 0.09 & 0.60 & 0.047 & 8.56 & 38.15 \\
\hline S. longicorne & 0.025 & 2.53 & 13.17 & & & & & & \\
\hline \multicolumn{10}{|l|}{ S. elongatum } \\
\hline Thysanopoda astylata & 0.002 & 0.23 & 1.61 & & & & & & \\
\hline Not identified & 0.057 & 5.75 & 16.36 & & & & 0.002 & 0.21 & 2.16 \\
\hline \multicolumn{10}{|l|}{ Juveniles and adults } \\
\hline Nyctiphanes simplex & 65.067 & 935.62 & 3235.35 & 94.506 & 1752.93 & 3976.39 & 92.391 & 2295.30 & 3578.88 \\
\hline Euphausia eximia & 4.832 & 69.48 & 188.16 & 2.384 & 44.22 & 105.03 & 2.980 & 74.02 & 175.81 \\
\hline E. gibboides & 0.534 & 7.67 & 22.23 & 0.037 & 0.69 & 2.61 & 0.412 & 10.23 & 33.81 \\
\hline E. tenera & & & & 0.091 & 1.69 & 5.72 & 0.034 & 0.83 & 2.95 \\
\hline E. hemigibba & 0.004 & 0.06 & 0.42 & & & & 0.005 & 0.13 & 0.65 \\
\hline E. distinguenda & 0.063 & 0.91 & 4.30 & 0.053 & 0.98 & 3.11 & 0.646 & 16.05 & 52.70 \\
\hline E. diomedeae & 0.016 & 0.23 & 1.61 & & & & & & \\
\hline E. recurva & 0.349 & 5.02 & 32.10 & 0.005 & 0.09 & 0.57 & 0.036 & 0.89 & 2.49 \\
\hline E. pacifica & 0.014 & 0.20 & 1.43 & & & & 0.010 & 0.24 & 0.83 \\
\hline E. lamelligera & & & & 0.112 & 2.08 & 12.82 & & & \\
\hline Nematoscelis difficilis & 21.814 & 313.67 & 1367.79 & 0.703 & 13.05 & 45.73 & 0.294 & 7.31 & 12.49 \\
\hline N. gracilis & 0.031 & 0.44 & 1.98 & 0.046 & 0.85 & 5.44 & & & \\
\hline N. tenella & 0.004 & 0.06 & 0.40 & & & & & & \\
\hline Thysanoessa gregaria & 0.199 & 2.87 & 11.41 & 0.197 & 3.65 & 19.29 & 0.016 & 0.39 & 1.96 \\
\hline Nematobrachion flexipes & 3.081 & 44.30 & 71.14 & 1.174 & 21.77 & 51.97 & 1.280 & 31.80 & 40.53 \\
\hline Stylocheiron affine & 3.308 & 47.56 & 79.26 & 0.685 & 12.70 & 37.83 & 1.680 & 41.75 & 51.55 \\
\hline S. maximum & 0.010 & 0.15 & 1.06 & 0.007 & 0.14 & 0.62 & 0.210 & 5.21 & 10.23 \\
\hline S. longicorne & 0.583 & 8.39 & 30.69 & & & & & & \\
\hline S. elongatum & 0.007 & 0.10 & 0.71 & & & & & & \\
\hline Thysanopoda astylata & 0.007 & 0.10 & 0.71 & & & & & & \\
\hline Not identified & 0.077 & 1.11 & 4.84 & & & & 0.006 & 0.16 & 2.05 \\
\hline
\end{tabular}

gibba and E. recurva, like the California Current terminus species, did not show recent evidence of reproduction during the study period (Fig. 5). Nyctiphanes simplex showed a latitudinal variation in the population structure and areas of reproduction. This is related to the seasonal coastal upwelling. During May 1986, extensive reproduction areas for $N$. simplex were found all along the peninsula, while during July and October 1987 the major portion of the reproductive population was observed in the northern zones. E. eximia in reproductive stages occurred in the north only during October 1987. During the other surveys, the reproductive stages were found in the southern regions (Fig. 5). The southern region was dominated by $E$. distinguenda, E. lamelligera, E. tenera, and Nematoscelis gracilis Hansen, all of which showed active reproduction. E. distinguenda was recorded close to Punta Eugenia during October 1987 (Fig. 5)

The relative abundances of 8 euphausiid species during ENSO 1982-1983 (Green 1986) and those ob- 

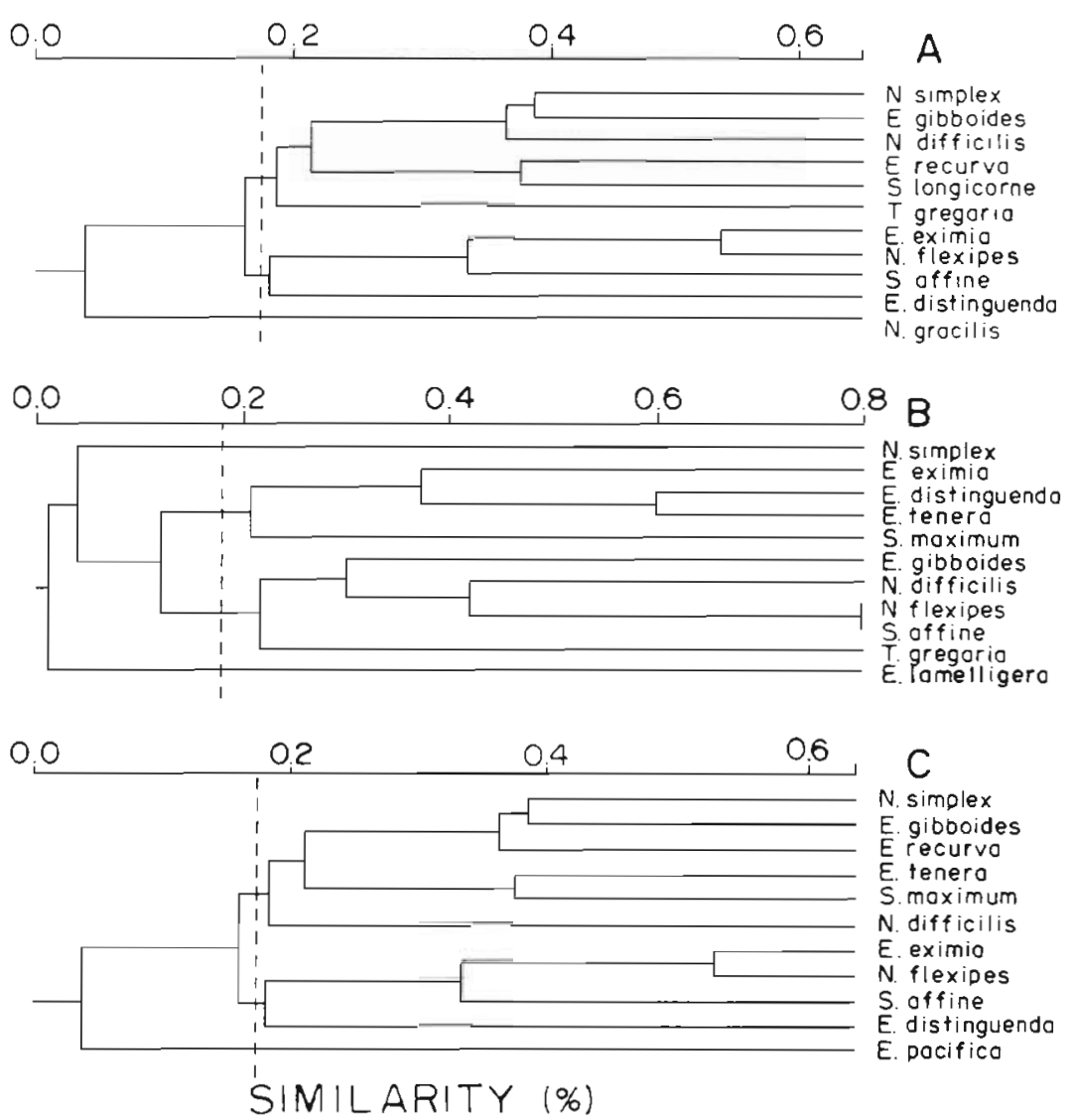

C

N. simplex

E. gibooides

E recurvo

E. tenero

S. moximum

N. difficilis

E. eximio

N. flexides

$S$ offine

E. distinguenda

E. pocifico

Fig. 4. Dendrogram of similarities (using the Jaccard index) between juveniles and adults of the euphausiid species collected during (A) May 1986. (B) July 1987, and (C) October 1987. Groups were estimated considering a similarity level $>0.2$. See Table 1 for species names in full

tained in this work during 1986 and 1987 close to Bahia Magdalena ( $23^{\circ}$ to $25^{\circ} \mathrm{N}$ ) were compared (Fig. 6). This shows that the ETP species Euphausia eximia, E. tenera, E. distinguenda, and E. lamelligera were very abundant during 1982 and 1983 and decreased during 1986, increasing again in summer 1987 (Fig. 6A). Nyctiphanes simplex and 3 temperate species (Nematoscelis difficilis, E. gibboides, and Thysanoessa gregaria) showed low abundance during ENSO 1982-1983, in comparison with the 1986 to 1987 period. Their greatest abundance was observed during spring 1986 (Fig. 6B)

\section{DISCUSSION}

The 1986-1987 ENSO event was reported to be a weaker warming event than ENSO 1982-1983 (Cole \& McLain 1989). A time series showed no evidence of a long-term warming during 1986 and 1987. It may have been obscured by ENSO 1982-1983, the most intense of the century (McGowan 1984, Brinton \& Reid 1986). During 1987, positive SST anomalies of greater than $1^{\circ} \mathrm{C}$ covered most of the equatorial Pacific and negative anomalies less than $-1{ }^{\circ} \mathrm{C}$ were confined to the mid-latitudes of the North Pacific (Kousky 1988). Our data confirm that the 1986-1987 ENSO event did not reach the Baja California peninsula in 1986 and early 1987, and only a weak warming was detected in the second half of 1987 south of $26^{\circ} \mathrm{N}$. In the area $5^{\circ} \mathrm{N}$ to $5^{\circ} \mathrm{S}$, the peak of the warm episodes of ENSO 1982-1983 was in January 1983 and for ENSO 1986-1987 in May 1987 (Wang 1992). Apparently a time difference of about 3 mo occurs between equatorial latitudes and the southern part of the peninsula of Baja California $\left(21^{\circ}\right.$ to $\left.26^{\circ} \mathrm{N}\right)$. This warming could be detected from July to December 1987 (21ํ to $24^{\circ} \mathrm{N}$ ) and from November to December at more northern latitudes $\left(24^{\circ}\right.$ to $\left.27^{\circ} \mathrm{N}\right)$, both showing an anomaly of about $1^{\circ} \mathrm{C}$.

Semiannual variability in both zooplanktonic biomass and geostrophic flow reported by Roesler \& Chelton (1987) suggests a relationship between zooplanktonic variability and advection of nutrients in the southern regions of the California Current. Longhurst (1967) reported that, after August, the northward-moving core of equatorial water may underlie a coastal undercurrent bringing tropical sea surface water up from the south and into the mouth of the Gulf of California and along the southwest coast of the Baja California peninsula. We suppose that a great part of the variability of SST is caused by the seasonal variations 


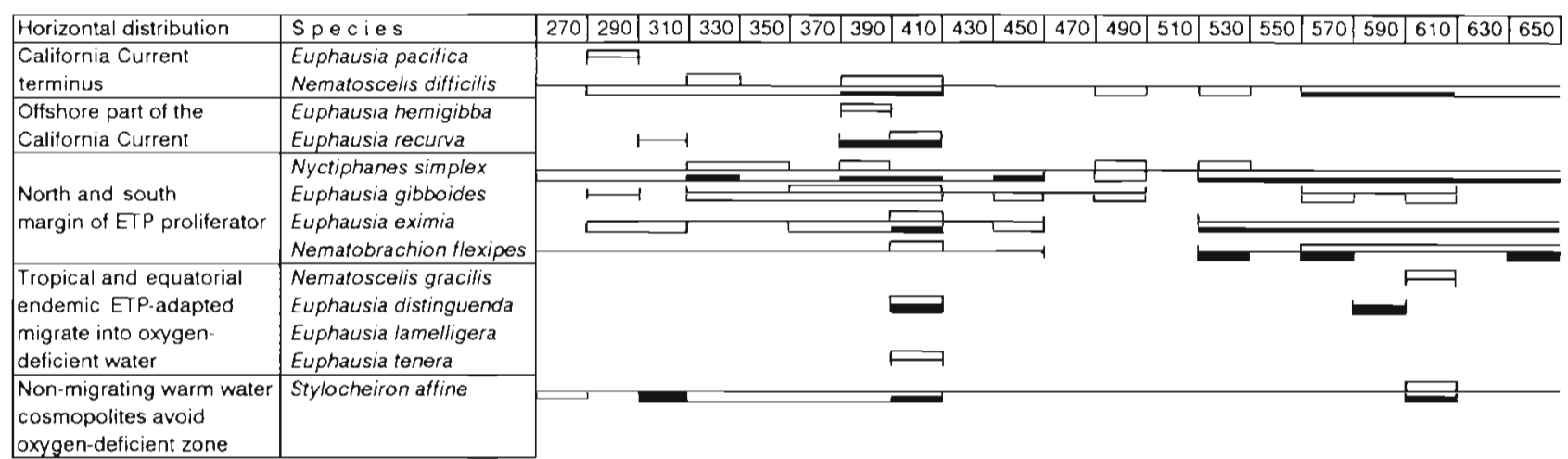

\section{July 1987}

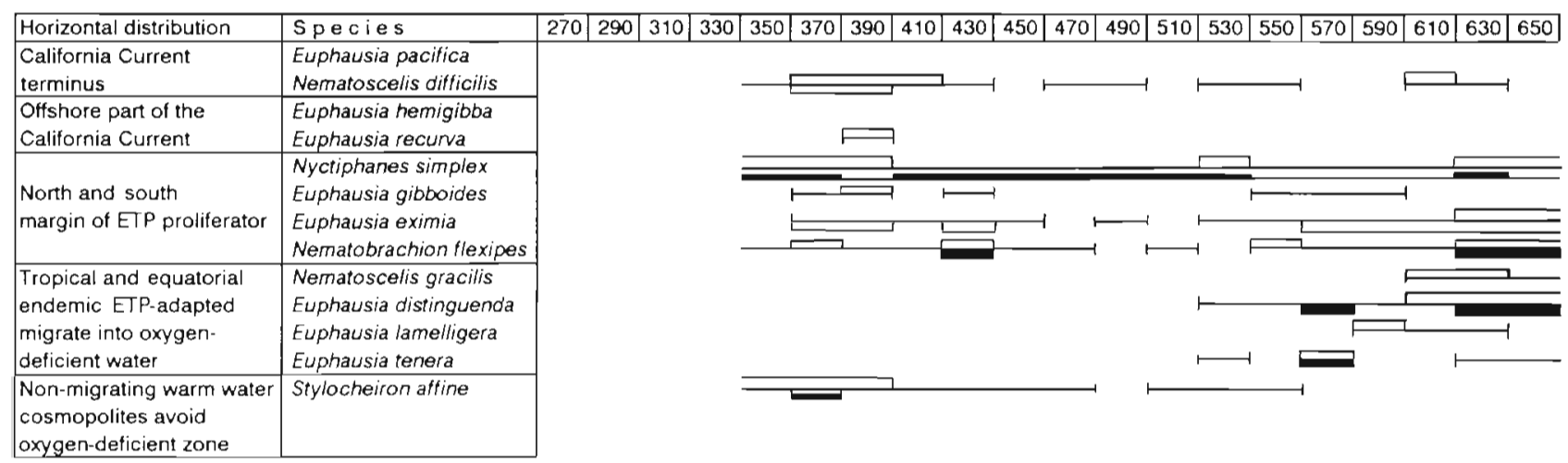

\section{October 1987}

\begin{tabular}{|c|c|}
\hline Horizontal distribution & Species \\
\hline $\begin{array}{l}\text { California Current } \\
\text { terminus }\end{array}$ & $\begin{array}{l}\text { Euphausia pacifica } \\
\text { Nematoscelis difficilis }\end{array}$ \\
\hline $\begin{array}{l}\text { Offshore part of the } \\
\text { California Current }\end{array}$ & $\begin{array}{l}\text { Euphausia hemigibba } \\
\text { Euphausia recurva }\end{array}$ \\
\hline $\begin{array}{l}\text { North and south } \\
\text { margin of ETP proliferator }\end{array}$ & $\begin{array}{l}\text { Nyctiphanes simplex } \\
\text { Euphausia gibboides } \\
\text { Euphausia exima } \\
\text { Nematobrachion flexipes }\end{array}$ \\
\hline $\begin{array}{l}\text { Tropical and equatorial } \\
\text { endemic ETP-adapted } \\
\text { migrate into oxygen- } \\
\text { deficient water }\end{array}$ & $\begin{array}{l}\text { Nematoscelis gracilis } \\
\text { Euphausia distinguenda } \\
\text { Euphausia lamelligera } \\
\text { Euphausia tenera }\end{array}$ \\
\hline $\begin{array}{l}\text { Non-migrating warm water } \\
\text { cosmopolites avoid } \\
\text { oxygen-deficient zone }\end{array}$ & Stylocheiron alfine \\
\hline
\end{tabular}
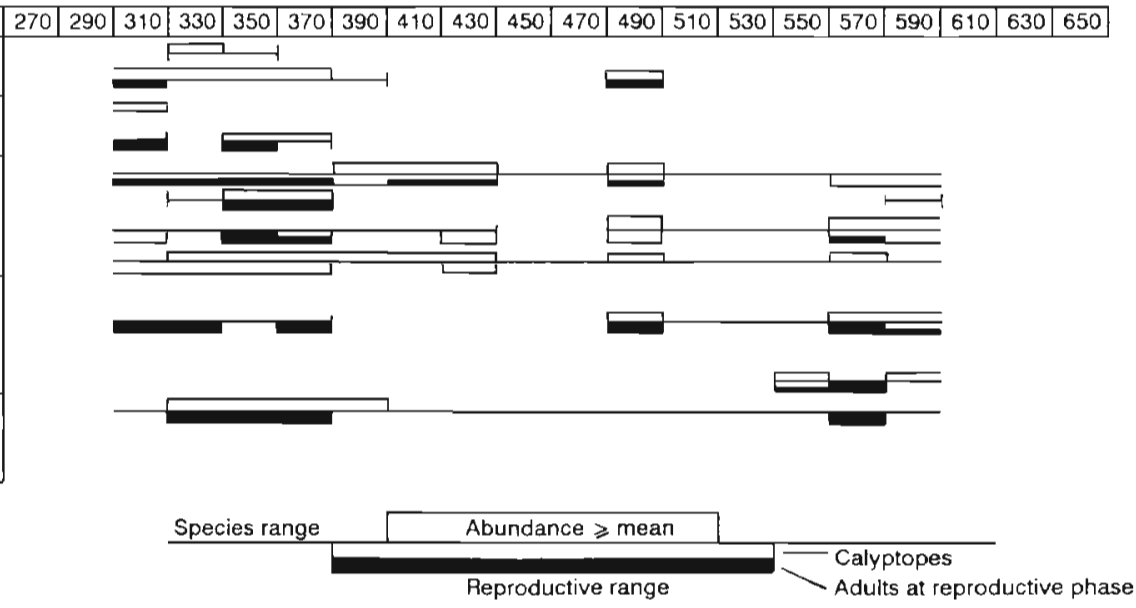

Fig. 5. Latitudinal distribution and abundance of the euphausiids along the west coast of Baja California, grouped by horizontal distribution types, showing the lines with the highest mean abundance and regions with reproduction evidenced by calyptopes ( $\square$ ) and adults in reproductive phase ( during May 1986, July 1987, and October 1987. Affinities defined in Brinton (1979)

in the environmental conditions of this region. However, this seasonal pattern could be modified by the weak warming occurring during the second half of 1987.
The environmental conditions prevailing during 1986 and 1987 favored the abundance of euphausids of the north margin ETP proliferator species (20\%) and the tropical and equatorial endemic ETP-adapted spe- 


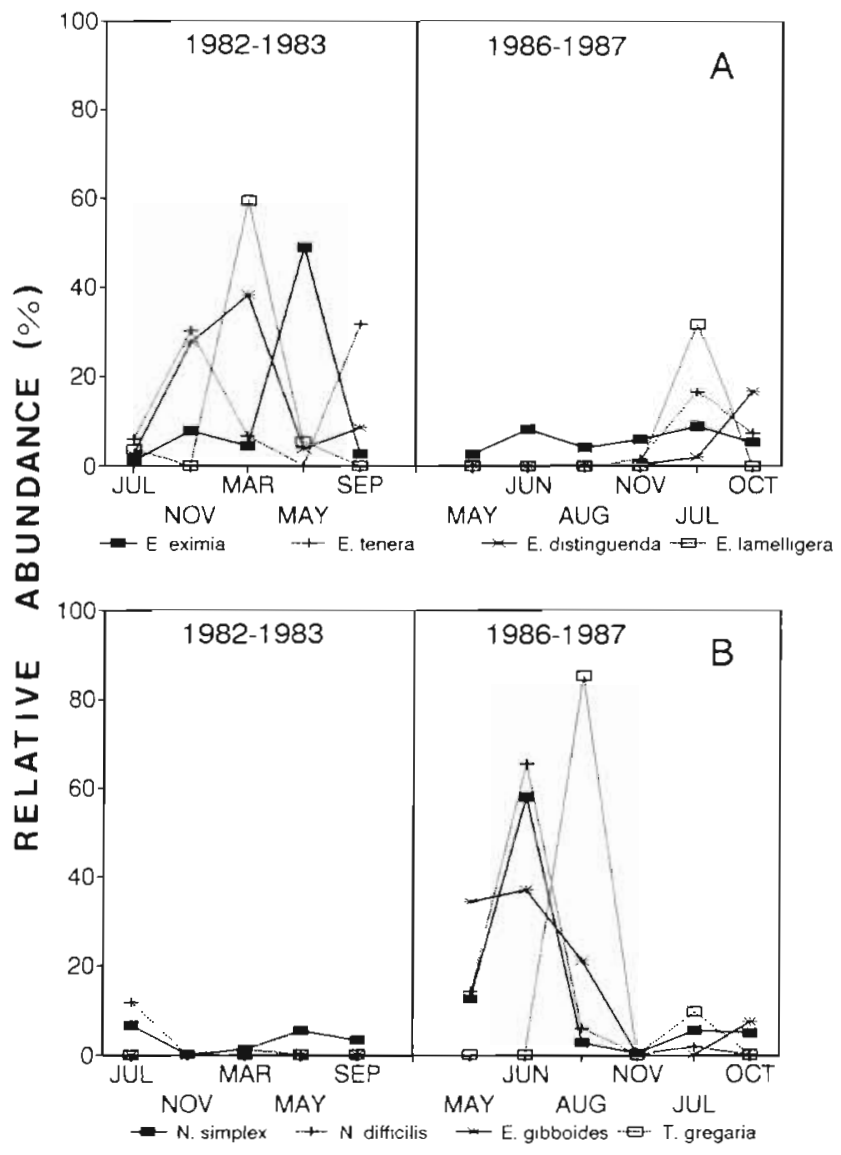

Fig. 6. Percent abundance of euphausiids sampled along the west coast of Baja California near Bahia Magdalena $\left(23^{\circ}\right.$ to $25^{\circ} \mathrm{N}$ ) during ENSO 1982-1983 (data obtained from Green 1986) and the period 1986 to 1987. (A) Tropical species; (B) temperate species. See Table 1 for species names in full

cies $(45 \%)$ over the California Current terminus species $(15 \%)$ and the offshore part of the California Current species $(10 \%)$, not including to the North Equatorial Countercurrent entrants $(10 \%)$. Based on the Jaccard index, when the California Current is strong (May 1986), tropical and temperate assemblages were spatially delimited in relatively similar proportions. During the onset of the northward movement of tropical waters, community structures of oceanic species remained well delimited with a tropical and a temperate assemblage. The coastal species, Nyctiphanes simplex and Euphausia lamelligera, were dominant in the coastal zone. When the warming peaked during the second half of 1987, causing tropical environmental conditions, a temperate-tropical mix assemblage distributed mainly in the northern area and a tropical assemblage dominating in the southern area were found.

This well-defined tropical assemblage found in October 1987, which had its most northern distribution (i.e.
Euphausia distinguenda), can be associated with environmental conditions of the weaker warming recorded during these years by Almeyda (1987), Cole \& McLain (1989), Lander (1989), and McPhander et al. (1990) for the Eastern Pacific Ocean. The peak of ENSO 1986-1987 was detected along the southern part of Baja California during the last months of 1987. Comparing the abundance of the tropical euphausiid species during 1982 and 1983 with 1986 and 1987 in Bahia Magdalena, low abundances were found during 1986 (May, June, August, and November). When we recorded a positive SST anomaly, the relative abundance of these species increased (July and October 1987).

Species show potential ranges in environmental conditions where development can be successful (Johnson \& Brinton 1963). These are determined by the physiological limits for species' survival. Frequently these ranges are best for reproduction. The suitability of habitat can be measured by the abundance of the species or by its capacity to reproduce there. In Fig. 5, abundance $\mathrm{m}^{-2}$ was used because it was felt that meaningful grouping here would be in terms of regional or zone adaptation, independent of the varying depths of the vertically migrating and nonmigrating species and of their various life stages (Brinton 1979). The temperature appeared to be the main environmental condition that influenced the temperate euphausiids to change distribution patterns as the environmental conditions became progressively adverse (Brodeur 1986).

Euphausia pacifica, found in May 1986 and October 1987, is believed to have moved from its reproduction areas because there was no evidence of recent reproduction. This species lives mainly off central California $\left(38^{\circ}\right.$ to $\left.33^{\circ} \mathrm{N}\right)$ and is dominant along with the temperate species Nematoscelis difficilis, Thysanoessa gregaria, and Thysanoessa spinifera Holmes (Brinton $1976,1981)$. The latter species was not found during our study. During cooler years, as in 1949 to $1955, E$. pacifica was more abundant than the ETP margin proliferator species along the west coast of Baja California (Brinton 1962, 1981, Brinton \& Reid 1986). However, the seasonal changes prevailing during 1986 and 1987 may have had an important influence in moving the $E$. pacifica population and other temperate species northward independently of the ENSO 1986-1987 recorded in lower latitudes. During ENSO events 1957-1958 (Brinton 1962), 1976-1978 (Brinton 1981), and 1981-1984 (Brinton \& Reid 1986), E. pacifica was not found along the Baja California peninsula $\left(25^{\circ}\right.$ to $\left.30^{\circ} \mathrm{N}\right)$

Other temperate species like Nematoscelis difficilis and Thyanoessa gregaria were possibly unfavorably influenced by the environmental conditions during 1986 and 1987. Although these species were found 
throughout the west coast, their reproduction areas, indicated by calyptopes stages and adults in reproductive stages, were shifted north. These species were more abundant during May 1986 when the influence of the California Current was more intense. This pattern was also observed by Brinton $(1960,1981)$. During July and October 1987, these species were found, and the number of calyptopes stages and adults in reproductive stages decreased with tropical environmental conditions.

Brinton (1979) showed Nyctiphanes simplex to be a proliferating species in coastal upwelling regions of the ETP. This species was more plentiful near shore than offshore ( $p<0.01$, Spearman). The reproduction areas are associated with upwelling regions, indicated by low SSTs and high values of zooplankton biomass $(p<0.01$, Spearman). It appears that the preference for upwelling regions by $N$. simplex is a general feature of the genus, which was also observed for Nyctiphanes couchii (Bell) (Le Roux 1973), and Nyctiphanes australis G. O. Sars (Bradford \& Chapman 1988, Hosie \& Ritz 1983) in other regions. Although Nyctiphanes capensis Hansen benefits from the productive waters of the Benguela region it appears to flourish in the warmer areas adjacent to the main upwelling centres (Barange \& Stuart 1991).

The distribution centers of Nyctiphanes simplex were associated with the SST of $20^{\circ} \mathrm{C}$. During May 1986, this species had its highest abundance from Bahia Magdalena northward. When the tropical countercurrent moved north during July and October 1987. its highest abundance and reproduction were moved progressively northward. This movement appears to be a response to the seasonal variation of the California Current System reported by Bakun \& Nelson (1977) and Lynn \& Simpson (1987, 1990). The northward movement could be stronger during years of anomalous warming. Three extensions of $N$. simplex beyond its usual distribution range have been previously reported along central and northern California; in 1958, and during 1977 and 1978, and 1982 and 1983, during unusually warm conditions in the California Current (Brinton 1981, Brinton \& Reid 1986, Brodeur 1986). These anomalous SSTs were associated with the northward flow of subtropical water due to ENSO conditions (Cole \& McLain 1989). This process produced the substitution of temperate species, such as $E$ uphausia pacifica and Thysanoessa spinifera for $N$. simplex (Brinton \& Willie 1976, Brinton 1981, Brodeur 1986). A similar change of species has been recorded in the southernmost regions of Baja California. Near Bahia Magdalena, we recorded a significant increase of tropical species and a drastic decrease of $N$. simplex and other temperate species during the second half 1987. In addition, in the northern area of the peninsula,
Nematoscelis difficilis peaked in cold periods and decreased in abundance as the water warmed, in direct contrast with the dynamics of $N$. simplex. Similar latitudinal displacement was reported for Euphausia lucens Hansen and $N$. capensis in the Benguela Current system (Barange et al. 1992).

During the 1982-1983 ENSO event, an anomalous local transport shoreward was observed (McLain et al. 1985). Several euphausiids from the Central Pacific could have moved by lateral diffusion toward inshore waters. During 1987, the presence of species from the Central Pacific, Euphausia hemigibba and E. recurva, indicated the influence of oceanic waters offshore at the transect lines 390 to 410 . During the anomalous warm years (1957 to 1959, 1977 and 1978, 1982 and 1983), these species became relatively more abundant in the California Current, where high production can persist close to latitude $25^{\circ} \mathrm{N}$ even when environmental conditions return to normal (Brinton 1962, 1979, 1981, Brinton \& Willie 1976, Brinton \& Reid 1986). These species, as well as the California Current terminus species, did not show any evidence of recent reproduction during the study period. We suggest these species were moved from their area of abundance.

Euphausia eximia, a marginal proliferator of the ETP (Brinton 1979), was very abundant in the offshore reproduction areas ( $p<0.01$, Spearman) associated with the subsurface warming and with the scarcity of zooplankton biomass ( $\mathrm{p}<0.01$, Spearman). Tropical species appear to inhabit water with SST $>26^{\circ} \mathrm{C}$ and dissolved oxygen of $<0.1 \mathrm{ml} \mathrm{l}^{-1}$ (Brinton 1979). In our work, these species had their highest abundance in the southern areas with SST greater than $22^{\circ} \mathrm{C}$ and low zooplanktonic biomass values. The broad-scale warming was also associated with a general shoreward shift in the limits of the ETP, particularly during July and October 1987 when a large number of tropical and equatorial endemic ETP-adapted species of euphausiids were observed at their northern limits. This northward displacement has been reported as part of the annual cycle of the California Countercurrent (Longhurst 1967).

Euphausia distinguenda, E. lamelligera, and E. diomedeae were observed close to Punta Eugenia in October 1987, where a population structure formed by adults in the reproductive phase suggests favorable environmental conditions for these species. During ENSO 1982-1983, these species showed a significant increase in their abundance compared with ENSO 1986-1987.

A strong northward transport of these species close to Punta Eugenia during July and October 1987 was possibly an effect of the warming recorded during this period. During September 1991, when a positive anomaly was observed along west coast of Baja Cali- 
fornia, a tropical species, Nematoscelis gracilis, was recorded north of Punta Eugenia (27 to $28^{\circ} \mathrm{N}$ ) (G. J. Gómez unpubl.). In our study this species remained south of there during 1986 and 1987, supporting the small effect of the 1986-1987 ENSO event on the euphausiid distributions.

There were 12 euphausiid species found off Bahia Magdalena during the 1982-1983 ENSO event. A major part of these were tropical and equatorial endemic ETP, and margin ETP proliferator species (Green 1986). The community structure and abundance of the euphausiids during ENSOs 1982-1983 and 1986-1987 showed differences. The displacement of temperate species by the northward movement of tropical species as a seasonal event is responsible for this change in the standing stock (Smith 1985). However, we thought both processes, seasonal and interannual variability, could be responsible for changes in the community structure and therefore of the standing stock. Temporal scales are difficult to separate. Comparison of euphausiid abundance between similar months during ENSOs 1982-1983 and 1986-1987 would exhibit some noticeable differences in amplitude and phase at different latitudes. The onset, as well as the peak, of both warm episodes occur in calendar months a half-year apart (Wang 1992). This makes it difficult to study the effect on the zooplankton community in a seasonal sequence.

Studies are ongoing to determine the population dynamics of the dominant euphausiids and to estimate the secondary production of the euphausiids in the southern part of the California Current System in relation to the species composition and change in the environment conditions.

The environmental conditions prevailing along the west coast of Baja California during 1986 and 1987 could be associated with the ENSO 1986 and 1987 recorded in the lower latitudes (Kousky 1988, Cole \& McLain 1989, Wang 1992). These conditions influenced the euphausiid species composition with dominance of margin ETP proliferators and tropical and equatorial endemic ETP adapted species. It did not favor the California Current terminus species Euphausia pacifica, Nematoscalis difficilis, and Thysanoessa gregaria, and the offshore California Current species $E$. hemigibba and E. recurva, which had moved out of their reproduction areas. This effect was less important than that observed during ENSO 1982-1983 off Bahia Magdalena. Future studies of euphausiid population dynamics could help to improve understanding of the effect of ENSO events on the distribution patterns along the west coast of Baja California, which is considered as a transition zone between the waters of the North, Central, and eastern tropical Pacific (Roden 1971).
Acknowledgements. Thanks to Dr Edward Brinton, Scripps Institution Oceanography (SIO), for advice on J.G.-G.'s M.Sc. thesis, and Annie Townsend (SIO) for her help in the identification of a large number of specimens. We are grateful to $\mathrm{Dr}$ Ellis Glazier for his editorial help with the English manuscript. This research was supported by funds provided by the Dirección de Estudios de Posgrado e Investigación (DEPI 903361) and by the Consejo Nacional de Ciencia y Tecnología (CONACYT D112-904620). We are grateful to the crew of the RV 'El Puma' for its cooperation. The authors are COFAA-IPN fellows. R.P.-G. and D.G. are also SNI fellows.

\section{LITERATURE CITED}

Almeyda, M. G. (1987). Características térmicas temporales del fenómeno de El Niño 1986/1987. Permanent South Pacific Commission. Bol. ERFEN 23: 19-21

Bakun, A., Nelson, C. S. (1977). Climatology of upwelling related processes off Baja California. Calif. coop. ocean. Fish. Invest. 19: 107-127

Barange, M., Pillar, S. C., Hutchings, L. (1992). Major pelagic borders of the Benguela upwelling system according to euphausiid species distribution. In: Payne, A. I. L., Brink, K. H., Mann, K. H., Hilborn, R. (eds.) Benguela trophic functioning, Vol. XII. S. Afr. J. mar. Sci., p. 3-17

Barange, M., Stuart, V. (1991). Distribution patterns, abundance and population dynamics of the euphauside Nyctiphanes capensis and Euphausia hanseni in the northern Benguela upwelling system. Mar. Biol. 109: 93-101

Beers, J. R. (1976). Volumetric methods. In: Steedmann, H. F. (ed.) Zooplankton fixation and preservation, Monographs on oceanographic methodology, Vol. IV. UNESCO Press, Paris, p. 55-60

Bradford, J. M., Chapman, B. (1988). Nyctiphanes australis (Euphausiacea) and an upwelling plume in western Cook Strait, New Zealand. N.Z. J. mar. Freshwat. Res. 22: $237-247$

Brinton, E. (1960). Changes in the distribution of euphausid crustaceans in the region of California Current. Calif. coop. ocean. Fish. Invest. 7: 137-146

Brinton, E. (1962). The distribution of Pacific euphausiids. Bull. Scripps Inst. Oceanogr. 8: 51-270

Brinton, E. (1967). Vertical migration and avoidance capability of euphausiids in the California Current. Limnol. Oceanogr. 12(3): 451-483

Brinton, E. (1976). Population biology of Euphausia pacifica off southern California. Fish. Bull. U.S. 74: 733-762

Brinton, E. (1979). Parameters relating to the distribution of planktonic organisms, especially euphausiids in the Eastern Tropical Pacific. Prog. Oceanogr. 8: 125-189

Brinton, E. (1981). Euphausiid distributions in the California Current during the warm winter-spring of $1977-78$, in the context of a 1949-1966 time series. Calif. coop. ocean. Fish. Invest. 22: 135-154

Brinton, E., Reid, J. L. (1986). On the effect of interannual variations in circulation and temperature upon euphausiids of California Current. In: Pierrot-Bults, A. C., Van der Spoel, S., Zahuranec, B. J., Johnson, R. K. (eds.) Pelagic biogeography, Vol. 49. UNESCO Tech. Paper, Paris

Brinton, E., Willie, J. G. (1976). Distributional atlas of euphausiid growth stages off southern California, 1953 through 1966. Atlas Calif. coop. ocean. Fish. Invest. 24: 1-289

Brodeur, R. D. (1986). Northward displacement of the euphausiid Nyctiphanes simplex Hansen to Oregon and Washington waters following the El Niño event of 1982-1983. J. crust. Biol. 6: 686-692 
Cole, A. D., McLain, D. R. (1989). Interannual variability of temperature in the upper layer of the North Pacific Eastern Boundary region, 1971-1987. NOAA Tech. Mem. NMFS

Gómez, G. J. (1992). Efecto de las condiciones ambientales sobre la abundancia de las poblaciones de eufáusidos (Crustacea) en la costa occidental de Baja California, durante mayo de 1986, julio de 1987 y 1988 . M.Sc. thesis, Centro Interdisciplinario de Ciencias Marinas, Instituto Politécnico Nacional, La Paz, Mexico

Green, R. Y. (1986). Variación cualitativa y cuantitativa de los eufáusidos (Crustacea: Malacostraca) en un ciclo estacional en el Pacífico Oriental de Baja California Sur. Degree thesis, Universidad Nacional Autónoma de México

Hosie, G. W., Ritz, D. A. (1983). Contribution of molting and eggs to secondary production in Nyctiphanes australis (Crustacea: Euphausiacea). Mar. Biol. 77: 215-220

Johnson, M. W., Brinton, E. (1963) Biological species, water masses, and currents. In: Hill, M. N. (ed.) The seas, Vol. 2. Wiley-Interscience, New York

Kousky, V. E. (1988). Climate diagnostic bulletin. December 1987. Climate analysis Center/NMC. NOAA 87/12:1-20

Lander, M. A. (1989). A comparative analysis of the 1987 ENSO event. Trop. Ocean-Atmos. Newslet. 49: 3-6

Lavaniegos, E. B., Lara, J. L. (1990). Zooplankton of the Gulf of California after the 1982-1983 El Niño event: biomass distribution and abundance. Pacif. Sci. 44: 297-309

Lavaniegos, E. B., Lara, J. L., Brinton, E. (1989). Effects of the 1982-1983 El Niño event on the euphausiid populations of the Gulf of California. Calif. coop. ocean. Fish. Invest. 30: $73-1987$

Le Roux, A. (1973). Observation sur le développement larvaire de Nyctiphanes couchii (Crustacea:Euphausiacea) au laboratoire. Mar. Biol. 22: 159-166

Longhurst, A. R. (1967). Diversity and trophic structure of zooplankton communities in the California Current. Deep Sea Res. 14: 393-408

Ludwig, A. J., Reynolds, J. F. (1988). Statistical ecology: a

This article was submitted to the editor primer on methods and computing. Wiley-Interscience, New York

Lynn, R. J., Simpson, J. J. (1987). The California Current System: the seasonal variability of its physical characteristics. J. geophys. Res. 92: 12947-12966

Lynn, R. J., Simpson, J. J. (1990). The flow of the undercurrent over the continental borderland off Southern California. J. geophys. Res. 95: 12995-13008

Makridakis, S., Weelwright, C. (1978). Forecasting methods and application. Wiley-Interscience, New York

McGowan, J. (1984). The California El Niño, 1983. Oceanus 27: $48-51$

McLain, D. R., Russell, E. B., Norton, J. G. (1985). Anomalous warm events in the boundary current systems. Calif. coop. ocean. Fish. Invest. 26: 51-64

McPhander, M. J., Hayes, S. P., Mangum, L. J. (1990). Variability in the Western Equatorial Pacific Ocean during the 1986-1987 El Niño/Southern Oscillation event. J. phys. Oceanogr. 20: 190-208

Roden, l. G. (1971). Aspect of the transition zone in the Northeastern Pacific. J. geophys. Res. 5: 3462-3475

Roesler, C. S. Chelton, D. B. (1987). Zooplankton variability in the California Current. Calif. coop. ocean. Fish. Invest. 28: 59-95

Smith, P. E. (1985). A case history of an Anti-Niño to El Niño transition on plankton and nekton distribution and abundances. In: Wooster, W. S., Fluharty, D. L. (eds.) El Niño effects in the Eastern Subartic Pacific Ocean. Washington Sea Grant, Seattle, p. 121-142

Smith, P. E., Richardson, S. L. (1977). Standard techniques for pelagic fish and larvae surveys. FAO Fish. tech. Pap. 175: $1-107$

Wang, B. (1992). The vertical structure and development of the ENSO anomaly mode during 1979-1989. J, atmos. Sci. 49: 698-712

Youngbluth, M. J. (1976). Vertical distribution and diel migration of euphausiids in the central region on the California Current. Fish. Bull. U.S. 74(4): 925-936

Manuscript first received: August 30, 1994

Revised version accepted: January 4, 1995 